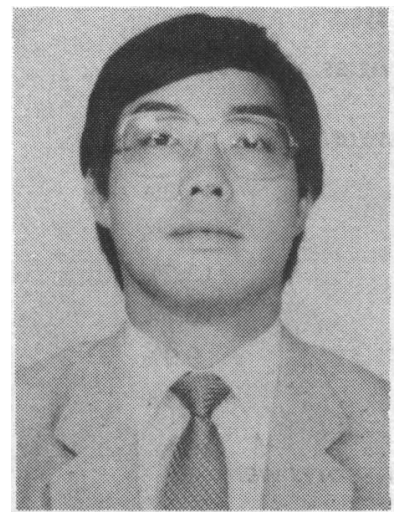

K. M. Chan

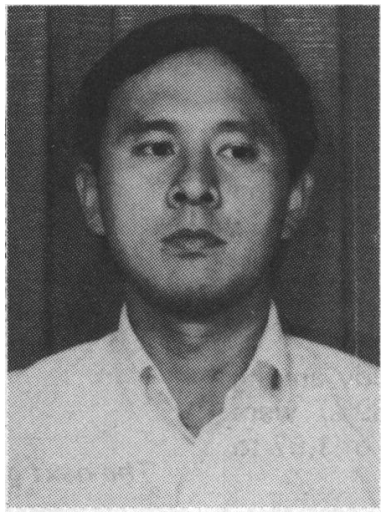

F. Fu

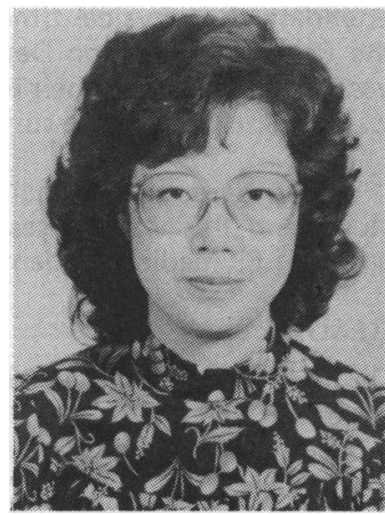

Louisa Leung

\title{
SPORTS INJURIES SURVEY ON UNIVERSITY STUDENTS IN HONG KONG $§$
}

\author{
K. M. CHAN, FRCS(E), ${ }^{*}$ F. FU, AB, MSc, DPE** and Louisa LEUNG, SRN, CM, HV† \\ "Dept. of Orthopaedic and Traumatic Surgery, " *Physical Education Unit, +University Health Service
}

\begin{abstract}
A sports injuries survey was conducted among 1714 students of the Chinese University of Hong Kong. The commorb sports involved in injuries were Soccer (26\%), Basketball (18\%), Cycling (11\%), Track and field athletics (11\%) and

. Swimming (10\%). The lower limb usually took the brunt of the injuries $(67 \%)$ followed by the upper iimb $(28 \%)$ an spinal injuries were relatively uncommon (3\%). The majority of the injuries were mild to moderate and the commonest ones were abrasion (37\%), contusion $(21 \%)$, cramp $(20 \%)$, sprains $(9 \%)$, and strains $(7 \%)$. Of the injuries $80 \%$ recovered in less than 10 days and $50 \%$ of them were self-treated. However, a significant group of more severe injuries was recorded: fracture, concussion and heat stroke which demanded special medical attention and longer period for recovery. The pattern of treatment was also unique in that traditional Chinese methods of treatment were sought more frequently than special orthopaedic advice. The preventive aspects of sports injuries was not well recognised with only $40 \%$ of the students regularly practising warm-up exercises, $18 \%$ stretching exercises and $4 \%$ using protective aids. More educational programmes and studies were indicated. The set up of a sports injury clinic is recommended with the utilisation of a sports injury reporting system.
\end{abstract}

\section{INTRODUCTION}

The affluence of a society may be reflected from the enthusiasm in sports. The "sports boom" that swept through America and Europe in the last two decades is gradually breezing to Hong Kong. With increasing participation in both fitness activities and competitive

\author{
Address for correspondence: \\ Dr. K. M. Chan \\ Department of Orthopaedic and Traumatic Surgery \\ The Chinese University of Hong Kong \\ Shatin, N.T. \\ Hong Kong
}

A joint project of the Department of Orthopaedic and Traumatic Surgery, Medical Faculty, University Health Service and Physical Education Unit, Chinese University of Hong Kong. sports, people are eager to learn how their bodies work during exercise and competition.

The Chinese University Health Centre Accident Report revealed that sports injuries accounted for a high incidence $(29 \%$ to $38 \%$ ) of injuries, attended at the University Clinic (Leung, 1982). There was evidence to indicate that sports injuries were common among the recreational sports as well as contact type of competitive games with peak seasons in October, November and March. A rising trend was also evident in recent years probably related to the increasing popularity of sports activities in the University. This is the first sports injury survey to be conducted in Hong Kong.

\section{METHOD}

This survey was primarily directed to the first year students of the Chinese University (1983-1984) 
attending the physical fitness assessment programme of the Physical Education Department. A group of second year students taking their electives in physical education was also included in the survey.

A standard questionnaire was used throughout the study and this was pre-tested in a pilot survey with a group of $\mathbf{5 5}$ medical students.

\section{RESULT}

Of the 1714 students participating in this study among which 1045 (61\%) were male and 668 (39\%) were female students giving a male to female ratio of 1.57 to 1.

\section{Age}

The majority of them were below 20 years of age (71.6\%) (Table I).

\section{TABLE I}

Age distribution.

$\begin{array}{lcc}\text { Age (yrs) } & \text { Number } & \text { Percentage } \\ 17-20 & 1222 & 71.5 \\ 21-25 & 464 & 27.0 \\ 26 \text { and above } & 28 & 1.5 \\ \text { Total } & 1714 & 100.0\end{array}$

Faculty

The distribution of faculty was illustrated in Table II.

\section{TABLE II}

Faculty distribution.

$\begin{array}{lc}\text { Faculty } & \text { Percentage } \\ \text { Arts } & 22.0 \\ \text { Science } & 28.6 \\ \text { Social Science } & 25.5 \\ \text { Business Administration } & 19.0 \\ \text { Medicine } & 4.9 \\ & 100.0\end{array}$

Relatively few medical students were sampled in this series chiefly because the Medical Faculty in this university is still young and the first class has only $\mathbf{8 0}$ students. A few of the clinical students come to the Sports Injury Clinic for treatment directly but they have been assured not to treat themselves before they qualify.

\section{Demographic Data}

The average height of the students was $167 \mathrm{~cm}$. The average weight of the students was $54.2 \mathrm{~kg}$.
TABLE III

Sports activities.

The five most popular sports were:-

$\begin{array}{lr}\text { (a) Swimming } & 15.3 \% \\ \text { Basketball } & 14.9 \% \\ \text { Cycling } & 13.2 \% \\ \text { Badminton } & 10.5 \% \\ \text { Soccer } & 9.9 \% \\ & 63.8 \%\end{array}$

The next group of less popular sports were:-

$\begin{array}{lr}\text { (b) Volleyball } & 9.5 \% \\ \text { Table tennis } & 8.4 \% \\ \text { Jogging } & 5.7 \% \\ \text { Track and field } & 5.3 \% \\ \text { Tennis } & 3.9 \% \\ & 33.0 \%\end{array}$

The least popular ones were:-

$\begin{array}{lc}\text { (c) Judo } & 0.16 \% \\ \text { Weight lifting } & 0.19 \% \\ \text { Softball } & 0.27 \% \\ \text { Hockey } & 0.28 \% \\ \text { Karate } & 0.30 \% \\ \text { Others } & 2.2 \% \\ & 100 \%\end{array}$

TABLE IVa

Nature of injuries.

$\begin{array}{lc}\text { Abrasion } & 37.1 \% \\ \text { Contusion } & 21.0 \% \\ \text { Cramps } & 20.4 \% \\ \text { Sprain } & 8.6 \% \\ \text { Strain } & 6.9 \% \\ & 94 \%\end{array}$

The less common but potentially more serious injuries were:-

TABLE IVb

Nature of injuries.

$\begin{array}{lcc}\text { Injuries } & \text { Percentage } & \text { No. of cases } \\ \text { Fractures } & 4.4 & 76 \\ \text { Concussion } & 0.7 & 12 \\ \text { Heat stroke } & 0.9 & 15\end{array}$


Sports injuries

The 5 main categories of injuries comprised $94 \%$ of the injuries sustained.

\section{Site of injuries}

The lower limb usually took the brunt of the injuries (67\%) followed by the upper limb $(27.7 \%)$ and the spine (2.36\%). The distribution of the 5 commonest sites were:-

\section{TABLE V}

Five commonest sites of injuries.

$\begin{array}{lc}\text { Leg \& Foot } & 37.7 \% \\ \text { Knee } & 19.2 \% \\ \text { Hand } & 18.1 \% \\ \text { Ankle } & 7.59 \% \\ \text { Elbow } & 6.00 \% \\ & 88.5 \%\end{array}$

Sports involved in injuries

The following five categories of sports comprised nearly $80 \%$ of the injuries sustained (Table VI).

\section{TABLE VI}

Five common sports involved in injuries.

$\begin{array}{lr}\text { Soccer } & 26.1 \% \\ \text { Basketball } & 17.8 \% \\ \text { Cycling } & 11.4 \% \\ \text { Track and field } & 10.8 \% \\ \text { Swimming } & 9.8 \% \\ & 75.9 \%\end{array}$

Patterns of injuries in the $\mathbf{5}$ groups of sports commonly involved in injuries were illustrated in Figs. 1-5.

\section{Treatment of Sports Injuries}

As the majority of the injuries were mild, special treatment was not often required. The pattern of treatment was illustrated in Table VII.

Recovery was usually fast for mild injuries. The duration required for the 3 most common injuries is shown in Table VIII.

On average $80 \%$ of the injuries recovered in less than 10 days. However for the more severe injuries, e.g. fracture, only $48 \%$ of them recovered in less than 10 days. $13 \%$ required 11 to 15 days, $12 \%$ required 16 to 30 days and $26 \%$ more than 30 days.

For ligament sprains and muscle strain, about $20 \%$ of them needed more than 10 days for recovery.
SOCCER IVUURI PATTERN IRBQUATCI BAR CEART

SITE

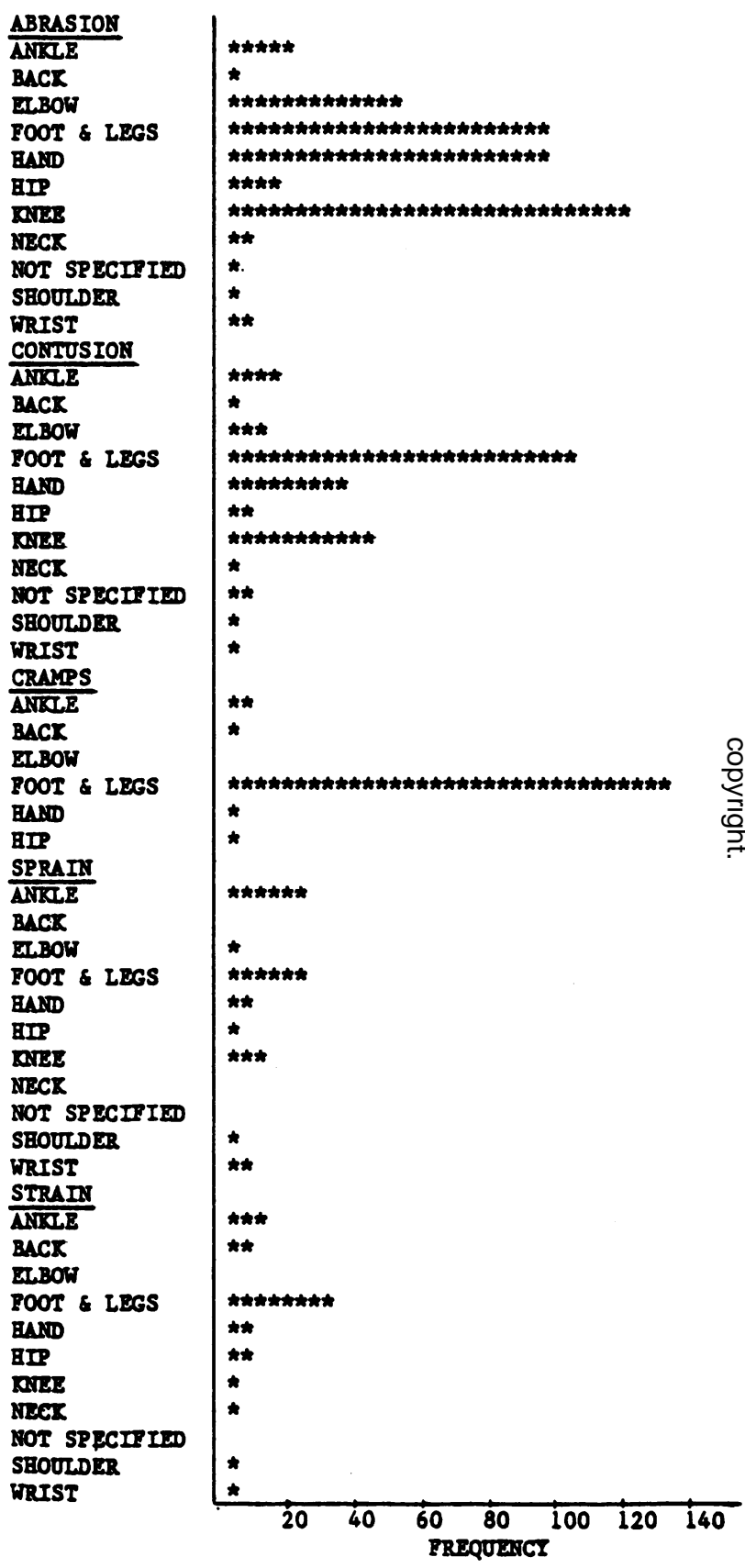

\section{FIGURE I}

When asked about their future preference of treatment of sports injuries the majority of the students selected the University Health Service (70.9\%) while $13.4 \%$ would like to have a specialist's opinion. 
SIIE

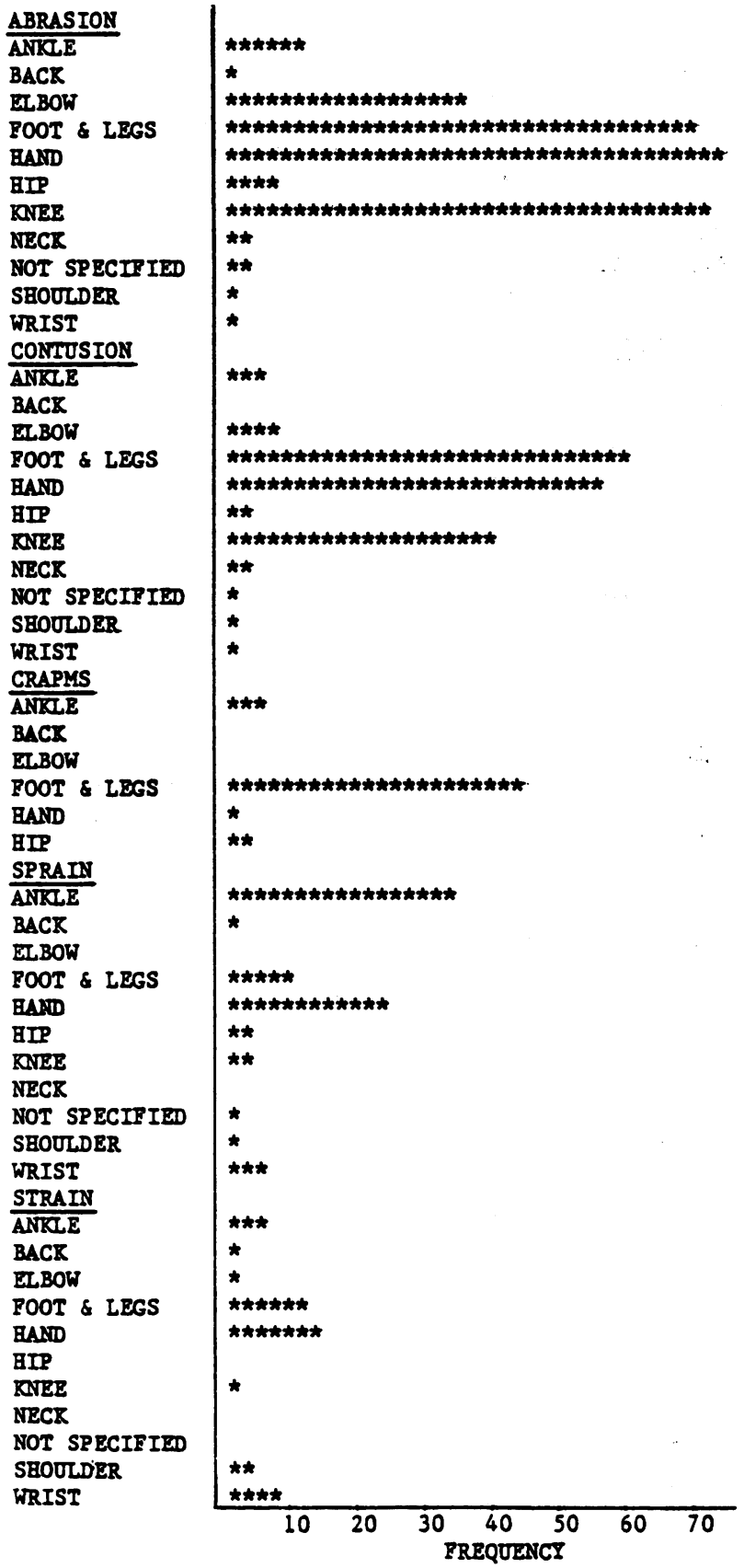

SITE FREQUENCI BAR CEART

\begin{tabular}{|c|c|}
\hline 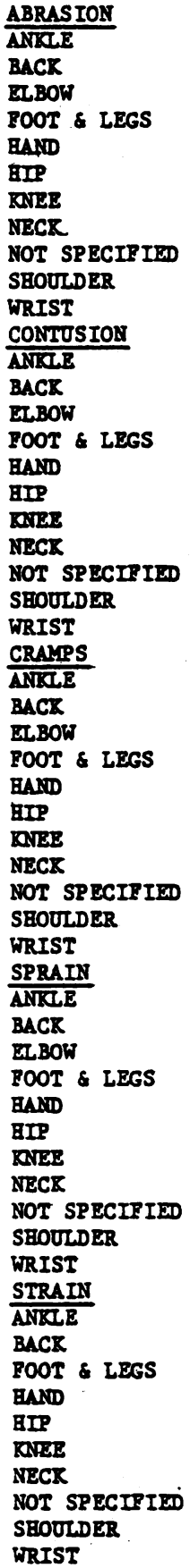 & 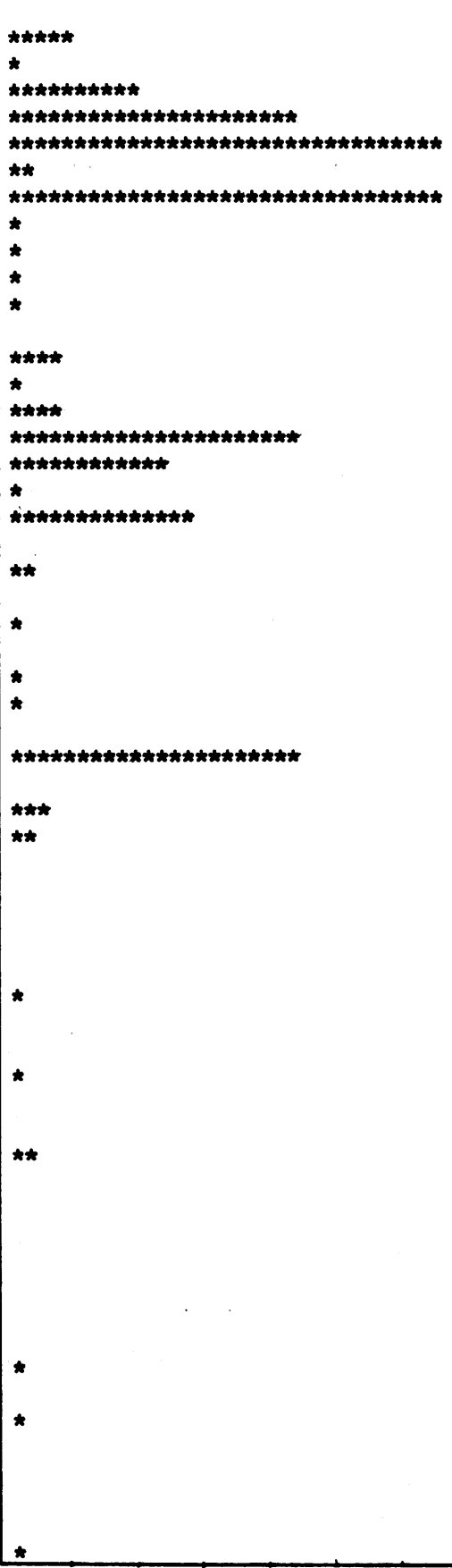 \\
\hline & $\begin{array}{llllll}10 & 20 & 30 & 40 & 50 & 60 \\
\text { FREQUEnCI } & & \end{array}$ \\
\hline
\end{tabular}


TRACR \& FIET INUURI PATTERH IREQUERICI BAR CRART

SITE

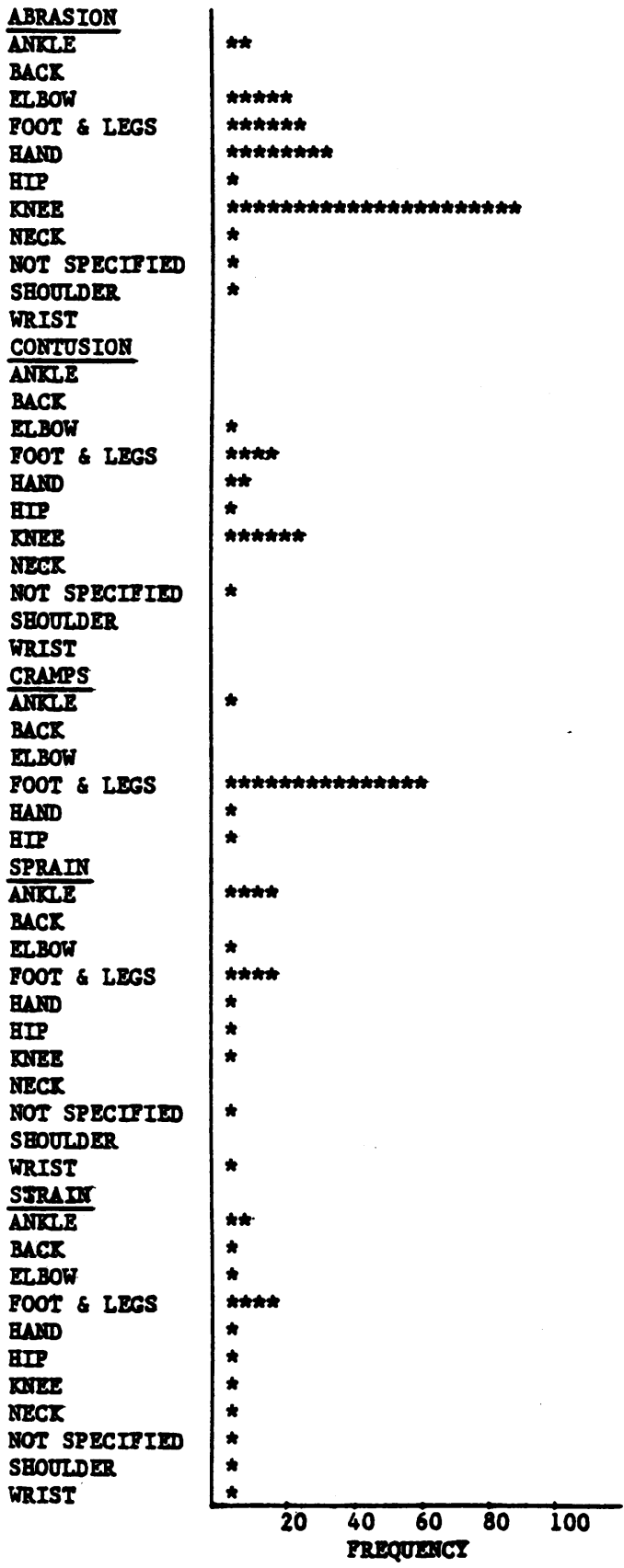

SWDATIEG IRUORI PATIERA BREQUUEICT BAR CEART

SIIE

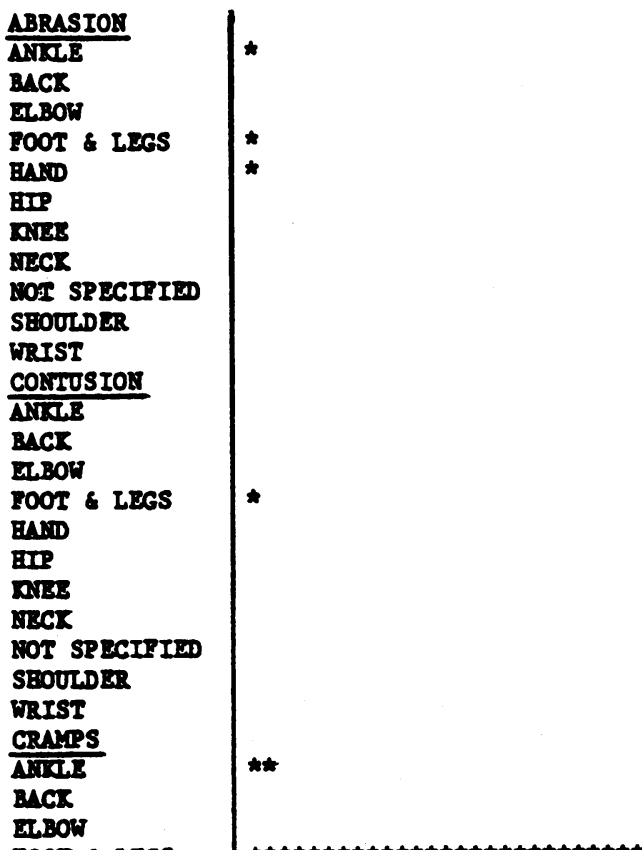

FOOT \& LEGS

BAND

EIP

LES

SECT

HOT SPECIIII

SEOULDER

WRIST

SPRAIR

ANRE

BMCK

ERBOW

FOOT \& IFGS

BNID

ETP

LIES

Heck

NOI SPECIPIND

SEOULDER

WRIST

STRAII

Alike

Back

ELBON

FOOT LBES

BNid

EIP

Dats

mect

BOT SPECITID SEOULDER

WRIST

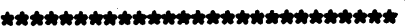
* 
TABLE VII

Pattern of treatment.

$\begin{array}{lr}\text { Self treatment } & 47.5 \% \\ \text { Treatment by friend/coach } & 7.9 \% \\ \text { Bone-setter } & 15.9 \% \\ \text { Doctor } & 13.7 \% \\ \text { Others } & 15.0 \% \\ & 100 \%\end{array}$

TABLE VIII

Recovery from three common injuries.

$\begin{array}{lccc}\text { Injuries } & \text { Less than } 2 \text { days } & 2-4 \text { days } & 5-10 \text { days } \\ \text { Abrasion } & 41 \% & 29 \% & 22 \% \\ \text { Contusion } & 39 \% & 28 \% & 24 \% \\ \text { Cramps } & 43 \% & 28 \% & 20 \%\end{array}$

\section{Prevention of Sports Injuries}

There were five categories of preventive measures enlisted. $42 \%$ of the students regularly practised warm up exercises; but the proportion dropped significantly for the other types of preventive measures:- $20 \%$ for warm down exercise, $18 \%$ for stretching, $7 \%$ assisted exercise and only $4 \%$ used protective aids (Table IX).

\section{TABLE IX}

Prevention of Sports Injuries.

$\begin{array}{lccc}\begin{array}{l}\text { Preventive } \\ \text { measures }\end{array} & \begin{array}{c}\text { \% of those } \\ \text { who knew }\end{array} & \begin{array}{c}\% \text { of those who } \\ \text { were taught }\end{array} & \begin{array}{c}\% \text { of those who } \\ \text { regularly practised }\end{array} \\ \begin{array}{l}\text { Warm up } \\ \text { exercise }\end{array} & 27 & 21 & 42 \\ \begin{array}{l}\text { Warm down } \\ \text { exercise }\end{array} & 25 & 17 & 20 \\ \begin{array}{l}\text { Stretching } \\ \begin{array}{l}\text { Assisted } \\ \text { exercise }\end{array}\end{array} & 19 & 10 & 18 \\ \begin{array}{l}\text { Protective } \\ \text { Aid }\end{array} & 17 & 8 & 7 \\ & 28 & 8 & 4\end{array}$

Formal teaching of these preventive measures was scanty; about $20 \%$ for warm up and warm down exercises and $10 \%$ or less for the others.

\section{DISCUSSION}

The management of sports injuries is an important field in the development of sports medicine. Any discipline needs research to continue its search for the truth and an education process for the application of such knowledge in practice. The first step in the understanding of sports injuries is an epidemiological survey from which the various facets of pattern of injuries, their treatment and prevention can be studied. The group of students in the Chinese University represents a unique group of young people regularly involved in sports as recreational exercises and competitions.

The five groups of commonest sports injuries: abrasion, contusion, cramps, sprain and strain comprise about $93 \%$ of all the injuries. The majority of them are minor injuries. This finding is in accordance with a similar student population survey done at the University of Manchester Sports Injury Clinic (Galasko et al, 1982), where soft tissue, ligament and muscle injuries account for $77 \%$ of all injuries.

The incidence of severe injury in this series is low: fracture $4.4 \%$, concussion $0.7 \%$ and heat stroke $0.9 \%$. Galasko also reported low incidence of fracture, $9 \%$, dislocation and subluxation $4 \%$. However this pattern is somewhat different from other reports, notably Weightman and Browne (1975) recorded the sports injuries treated in hospital over one year and found that fractures and dislocation were responsible for $35.4 \%$ whereas soft tissue injuries only $21.5 \%$. The disparity is probably due to the fact that the more severe injuries, such as fractures are channelled to the hospital primarily giving a concentrated and high incidence. The figures in our series probably indicated a more accurate analysis of the real incidence of sports injuries.

The types of sports are similar to other series soccer, basketball, cycling are the top three categories. Muckle and Shepherdson (1975) listed rugby, ski-ing and football while Galasko and colleagues (1982) reported soccer, rugby and athletics as the commonest varieties. The common feature is that the contact type of ball games are more prone to injuries. However there are obvious variations in the climate, national interest and availability of facilities.

In this series, the lower limb injuries are more common (67\%) with the leg and foot $(38 \%)$, knee $(20 \%)$ particularly vulnerable. This is similar to the Manchester experience (Galasko et al, 1982) in which $65.6 \%$ are lower limb injuries with the knee (24\%) and the ankle (14\%) most commonly involved. A totally different spectrum of sports injuries in children (age 6 to 17) was reported by Chamber (1979) in which the upper limb was involved in $80 \%$ of the cases.

A closer analysis of the type and site of injuries involved in the three commonest sports gives better understanding of the actual pattern. In soccer, the common injuries are abrasion of the knee, leg, foot and hand; contusion of the leg and knee and cramps in the leg. This finding is in agreement with other series which reported that among professional and intercollegiate footballers knee and ankle injuries are the commonest (Muckle, 1978; Canale et al, 1981; Biener, 1982). 
In basketball, the pattern of injuries is slightly different in that the hand is understandably and commonly involved with abrasion and contusion. However the knees and ankles are also common sites. Henry et al (1982) reported that among professional basketballers the most common as well as the most severe injuries were those of the ankle and knee.

Cycling in the campus is more a recreational exercise than a competitive sport. The injuries are often trivial with abrasion and contusion in the legs and hands as well.

It is difficult to give an accurate analysis of the probabilities of injuries in this study because of the myriad of variables involved in different types of students, novices and school team participating in different types of sports with different interest level and experience. However the interesting point revealed from comparing the number of participant and the number of injuries reported in that particular sport indicate that badminton, tennis and table-tennis are relatively "safe" sports and incidentally these are non-body-contact racquet types of sports. Soccer, track and field, basketball are relatively "risky" types of games.

The pattern of treatment and recovery also reflected the severity of the injuries. As the majority of injuries are mild almost $50 \%$ of them are self-treated and $80 \%$ recovered in less than 10 days.

However the more severe type of injury e.g. fractures should be managed more cautiously as nearly $30 \%$ of them require more than $\mathbf{3 0}$ days for recovery. It may also be of interest to note that the bone-setter's treatment is more often sought (15.9\%) than attending a doctor $(13.7 \%)$. This trend of treatment is related to a strong traditional background and is expected to be even more prevalent among the professional and amateur sports teams. The traditional Chinese method of treating sports injuries include the use of herbs, massage, acupuncture and moxibustion (Xian, 1984). The scientific basis of these methods need to be explored with further research. More information is required to delineate the exact role of the sports physician and the sports medicine team in this aspect.
In case of future sports injuries, $71 \%$ of the students preferred to attend the University Health Service and $13 \%$ of them would like to have a specialist's opinion. A sports injury clinic should provide the appropriate service to such a high demand and also serve a good opportunity for further research in treatment and prevention.

The prevention aspects of sports injuries is not well recognised among the students. Only $42 \%$ regularly practised warm up exercises, $20 \%$ did warm down exercises and $18 \%$ stretching exercises. There are also indications that teaching of these preventive measures and first aid treatment will be very much appreciated and perhaps should take the format of regular courses for both students and coaches.

\section{CONCLUSION}

This is the first study of this nature to be conducted in Hong Kong. It is envisaged that the identification of injury patterns and the realisation of preventive measures are equally important. The setting up of a special sports injury clinic is recommended to provide both immediate primary care to the athletes as well as expert treatment. A special sports injury reporting system should be adopted for documentation anc research. The Canadian Athletes Injury Reporting System (CAIRS) may be a suitable model. It is hoped that a growing body of information can be collected and analysed. This is obviously the first step towards a better service on sports medicine for the local community.

\section{ACKNOWLEDGEMENTS}

The authors would like to thank the following colleagues for their advice and generous help without which this study would not have been completed:

Mr. Aaron Lee of the Physical Education Unit, Mr. Edwin Laio and Ms. Maria Chan of the Computer Centre, Dr. C. F. Lo and Dr. Robert Dan of the University Health Service and Prof. P. C. Leung of the Department of Orthopaedic and Traumatic Surgery and the coaches, physical education instructors and the medical students.

"Moxibustion is a method of producing analgesia by counter-irritation by igniting moxa, wormwood or other combustible materials and holding the slowly burning substance near to the skin overlying a lesion, to produce heat but without causing burning or pain. - Editor.

\section{REFERENCES}

Biener, K., 1982 "Sports injuries in different types of sports". Soz Praventivmed. 27: 16.

Canale, S. T., Cantler, E. D. Jr.; Sisk, T. D. and Freeman, B. L., 1981 "A chronicle of injuries of an American intercollegiate football team". Am.J.Sports Medicine 9: 384.

Chambers, R. B., 1979 "Orthopaedic injuries in athletes (age 6 to 17). Comparison of injuries occurring in six sports". Am.J.Sports Medicine 7: 195. 
Galasko, C. S. B., Menon, T. J., Lemon, G. J., Banks, A. J., Morris, M. A., Bourne, M. S. and Bentley, S., 1982 "University of Manchester sports injury clinic". Brit.J.Sports Medicine 16: 23-26.

Henry, J. H., Lareau, B. and Neigut, D., 1982 "The injury rate in professional basketball". Am.J.Sports Medicine 10: 16.

Leung, L., 1982 “Accident Report of Chinese University Health Centre”. Personal Communication.

Muckle, D. S. and Shepherdson, H., 1975. Football Fitness and Injuries, Pelham, London.

Muckle, D. S., 1981 “Injuries in professional footballers”. Brit.J.Sports Medicine 15: 77.

Weightman, D. and Browne, R. C., 1975 “Injuries in eleven selected sports”. Brit.J.Sports Medicine 9: $136-141$.

Xian, H. Z., 1984 "The treatment for sports injuries - the traditional Chinese method". Proceedings of the Hong Kong Sports Medicine Conference. In Press.

\section{BOOK REVIEW}

Title: SPORT, GAME, gYMNASTICS IN THE SECOND PART OF LIFE (LIFE - TRAINING TEACHING - ORGANISATION)

Author: Heinz Meusel, Giessen University/F.R. Germany Sports Science Centre

Publishers: $\quad$ Limpert, Bad Homburg. Language: German

Price: DM 35, $\quad 335$ pages, numerous tables, graphs, and figures. ISBN 3785314019

Only in the last two decades sport for older people has been established among the varieties of physical exercise offered especially in bigger athletic clubs but also in those run by private organisations. In general, the knowledge of sports physicians about the physiological decrease caused by age ("biomorphosis") with its consequences for the function of organs including the psychic and social components is still poor. Considering the fact that mankind gets older and older and becomes more and more inactive because of an increasing lack of motion the reviewed book becomes especially important, it eliminates so to say a blank spot on the map of physical activities.

The author, professor of physical education and a well-known researcher of sport with older people revised 5000 essays about sport medicine, training science, and sports pedagogy. And thus not only a documentation with many references about sport with older people has been produced but in spite of the scientific character this book is first of all written for every-day use. There are plenty of practical and well tried hints and suggestions e.g. for the organisation of sport with the aging or time-tables for the naturally very different conditions of the training with older people.

It is necessary to lay stress upon the extensive chapter 3 about the training contents. The important role of endurance training of older people is well-known. But the author also confirms why for example special forms of strength training are of great importance. Afterwards the components of fastness, flexibility, equilibrium, and coordinating capacities are shown concerning the advantage and disadvantage for the training programme of older people. In another chapter different sports disciplines are examined according to their applicability for the sport with the aging. In the beginning he thereby critically reports different options, in the end he, however, offers concretely confirmed programmes. Good schematic and tabular surveys systematise the extensive topic. Another chapter deals with didactic drafts, i.e. with the practise of teaching by sport teachers. Here one can notice much pedagogic and practical experience of the author. Besides this, topics like the prevention of accidents, examinations by sports physicians, overstressing, sport motoric tests, and dosage of physical exercise in sport with the aging are discussed, but also biological, psychological, and sociological problems of aging.

This book which in spite of plenty of material has been written as briefly as possible can be recommended to the trainers as well as to sport physicians.

E. D. Lübs

Professor of Cardiology, University of Kassel, Germany

Dr. Heinz Meusel contributed an article to Brit.J.Sports Med. 18:1, pages 4-12 earlier this year on some of the topics mentioned in his book. - Editor 